\title{
Oils of insects and larvae consumed in Africa: potential sources of polyunsaturated fatty acids
}

\author{
Hilaire Macaire WOMENI ${ }^{1}$ \\ Michel LINDER ${ }^{2}$ \\ Bernard TIENCHEU ${ }^{1}$ \\ Félicité Tchouanguep MBIAPO ${ }^{1}$ \\ Pierre VILLENEUVE ${ }^{3}$ \\ Jacques FANNI ${ }^{2}$ \\ Michel PARMENTIER ${ }^{2}$ \\ ${ }^{1}$ Université de Dschang, Faculté des Sciences,
Département de Biochimie, BP 67 Dschang,
Cameroun
$<$ womeni@yahoo.fr'
${ }^{2}$ ENSAIA-INPL, Laboratoire de Science et Cénie
Alimentaires, 2 avenue de la forêt de Haye,
54500, Vandoeuvre-les-Nancy cedex, France
${ }^{3}$ CIRAD, UMR IATE, Laboratoire de Lipotechnie,
TA 40/16, 73 rue JF Breton,
34398 Montpellier cedex 5, France
}

\section{Introduction}

Insects are known to constitute more than $76 \%$ of the animal kingdom [1]. There exist in Africa, more than 500 species of insects used as food by the indigenous population and play a significant role in the history of the nutrition. Several species are often considered as devastators of harvests (grasshoppers, weevil), whereas others (winged termites, raphia weevil larvae, caterpillars, crickets, bees, maggots, butterflies...) are significant sources of food [2]. In many tropical countries, insects captured without control in nature, are consumed by the local populations or are used for other tools. The "palm weevil", various caterpillars, termites and many other insects serve as food of choice for man in several countries. Maggots are sometimes given to fowls or pigs in village breeding houses. In industrialized countries, besides the fact that insect chitin can significantly reduce serum cholesterol level, non-

\begin{abstract}
The objective of this paper is to present the beneficial aspects of some insects consumed in sub-Saharan Africa, based on examples of insects consumed in Cameroon, to present their potential as sources of lipids and essential fatty acids. In Africa, termites, larvae of raphia weevil, caterpillars, crickets, bees, maggots, butterflies, weevil, etc. are significant sources of food. These insects belong mainly to the orders of: Isoptera, Orthoptera, Dictyoptera, Coleoptera, Hymenoptera, Lepidoptera and Diptera. Depending on the species, insects are rich in proteins, minerals ( $K, \mathrm{Ca}, \mathrm{Mg}, \mathrm{Zn}, \mathrm{P}, \mathrm{Fe})$ and/or vitamins (thiamine/B1, riboflavine/B2, pyridoxine/B6, acid pantothenic, niacin). The composition of oils extracted from the following six insects consumed in Cameroon was investigated: larvaes of raphia weevil (Rhynchophorus phoenicis), crickets (Homorocoryphus nitidulus), grasshopper (Zonocerus variegates), termites (Macrotermes sp.), a variety of caterpillars (Imbrasia sp.) and an unidentified caterpillar from the forest (UI carterpillar). The extraction yields of oil were $53.75 \%, 67.25 \%, 9.12 \%, 49.35 \%$, $24.44 \%$ and $20.17 \%$ respectively for raphia weevil larvae, crickets, devastating crickets, termites, Imbrasia and UI caterpillar. The oil from raphia weevil mainly contains $37.60 \%$ of palmitoleic acid and $45.46 \%$ of linoleic acid. The oil from crickets is principally made up of palmitoleic acid (27.59\%), linoleic acid (45.63\%) and $\alpha$-linolenic acid (16.19\%). The oil from grasshoppers is composed of palmitoleic acid (23.83\%), oleic acid (10.71\%), linoleic acid (21.07\%), a-linolenic acid (14.76\%) and $\gamma$-linolenic acid (22.54\%). The main components of termite oil are: palmitic acid (30.47\%), oleic acid (47.52\%) and linoleic acid (8.79\%). Palmitic acid (36.08\%) and linolenic acid (38.01\%) are the two dominant fatty acids of Imbrasia oil. As Imbrasia oil, UI caterpillar oil is composed of palmitic acid (30.80\%) and linolenic acid (41.79\%). Stearic acid (7.04\%), oleic acid (8.56\%) and linoleic acid (6.59\%) are also present. These results show that these insects are considerable sources of fat. Their oils are rich in polyunsaturated fatty acids, of which essential fatty acids are linoleic and linolenic acids. The ratio PUFA/SFA, in the majority of cases is higher than 0.8, associated with desirable levels of cholesterol.
\end{abstract}

Key words: Edible insects, Rhynchophorus phoenicis, Homorocoryphus nitidulus, Zonocerus variegates, Macrotermes sp., Imbrasia sp., carterpillar, oils, essential fatty acids

food uses of certain carnivore larvae of Diptera play an importance role in surgery [3]. Cultural practice of entomophagy dates centuries backward [4]. In developing countries, entomophagy is encouraged by the fact that animal proteins are expensive for the underprivileged populations and also due to the hypercholesterolemic effect of certain foodstuffs. Insects are valuable sources of proteins in certain regions of Zambia, where wild animals are rare [5]. A 10\% increase worldwide of the protein mass via the entomophagy, would eliminate the problem of malnutrition and decrease the pressure exerted on the other sources of proteins [6]. In Nigeria, studies have showed that entomophagy contributed significantly to a reduction of protein deficiency [7-9]. Zambia and Nigeria, as well as other developing countries face nutritional problems due to the insufficiency of protein sources, carbohydrates, fatty acids and minerals salts. Moreover, the nutritional diseases such as; cardiovascular diseases, diabetes and obesity, related to the consumption of fat are become recurring in our countries. The fight against these plagues can be done by, assuring food safety (via the new sources of food) and by education of the population on the food products which they consume. It was proven in certain American and European countries that proteins and fats from insects have an effect on the reduction of cardiovascular and digestive diseases. This beneficial effect on health was associated to the hypocholesterolemic effect of monounsaturated fatty acids (MUFA) and polyunsaturated fatty acids (PUFA) contained in certain edible insects [10]. Unfortunately, these insects are not very often consumed for their beneficial effects. In Africa, insects are one of the immediate sources of fatty acids and proteins used to satisfy the elementary need. As a result, edible insects must be looked upon as alternative sources for the food problems faced in Africa. The objective of this paper is to give highlights 
on the nutritional aspects of insects consumed in sub-Saharan Africa, based on some examples of insects consumed in Cameroon, and to show their potential as a valuable source of lipids and essential fatty acids.

\section{Insects consumed in sub- Saharan Africa and their place in the food safety}

Since time immemorial, insects have contributed significantly as food to many populations and cultures.

Edible insects are very popular with the Indians of North America, in Mexico, as well as in many Asian and African cultures [4]. They are particularly important in Amazon, Congo basin and in South Africa, where they are regarded as a priceless source for the role they play in their tradition, medicine and diet [11]. Nowadays, insects are consumed like a daily supplement, an occasional dish or a substitute product during food shortages.

The most consumed groups of insects are: Coleoptera (half being Cerambycidae and Scarabaeidae) [12], Lepidoptera (especially in the form of caterpillar or chrysalis) [12], Hymenoptera (majority being Meliponidae) [13], Orthoptera (especially Acrididae) [14-17] and some other groups which include termites (Isoptera), Hemiptera, etc. Certain species such as Edessa cordifera, Rhynchophorus phoenicis, Imbrasia ertli, Cirina forda, Anaphe sp., Gonimbrasia belina, Gynanisa maia, and the family of Notodomidae, Curculionidae, Saturniidae, etc., are besides largely preferred. Caterpillars and termites (winged adults) are the insects most consumed and marketed in Africa, but many other kinds or species are locally important, whether for economic reasons, ecological or nutritional.

In South Africa, Pedis highly appreciate insect meals compared to other meals. During the harvest periods of caterpillars (Gonombrasia belina), beef sales experience a significant fall in demand [18]. An estimation in the 1960's indicated that more than 1600 tons of caterpillars of this species was collected each year, without taking into account the quantifies of caterpillars directly consumed by the caterpillar-collectors. Hundreds of tons, collected in South Africa and in Bostwana were marketed in Zambia and Zimbabwe.

In Angola, Oliveira et al. [19] mentioned some consumed species, amongst which one termite (Macrotermes subhyalinus), a larva of Curculionidae living in palm trees (Rhynchophorus phoenicis) and a caterpillar (Usta terpsichore) were present. In Malawi, many species of insects are consumed, sometimes in a seasonal way. The consumption of caterpillars of Gonimbrasia belina and Gynanisa maia in the park of Kasungu, is made in mid-
October to December, which is the period of the year with lowest food reserves. Moreover, authorization from the persons in charge of the park to harvest the caterpillars, contributes to maintenance of biodiversity. There is also consumption of the adults of a Diptera Chaoborus edulis in this same region.

In Uganda, the larvae of many species of the larger beetles are sought and eaten but are not as important as termites and grasshoppers in the diet. Chaoborus spp., adult lake fly, cakes are eaten and are possibly an important source of protein in Uganda [20].

In Nigeria, entomophagy is largely widespread, but more common in the rural zones than in the urban zones. As in other regions, the most educated social class readily gives up entomophagy, considering it to belong to the past. As in other African countries, the caterpillars Cirina forda are highly appreciated, sold relatively to their weight and twice more expensive than the meat of beef [21]. Termites (Macrotermes bellicossus) are eaten in several parts of western Nigeria. The winged adults are usually caught while on their nuptial flight or collected from the ground after they have shed their wings and then roasted for eating. The variegated grasshopper (Zonocerus variegates) which has a large dry season population in southwestern Nigeria is reported eaten in Akoko area of Ondo State [9]. The larvae and pupae of honeybees (Apis mellifera) have very high protein content. Edible insects constitute an important part of the daily diet of a large proportion of the population in southwestern Nigeria. These insect provide high quality of proteins and supplements (minerals and vitamins) even when dried [22].

In the Democratic Republic of Congo, more than 65 species belonging to at least 22 different families are consumed. A study in 1961 [23] estimated that insects represent $10 \%$ of the origin of animal proteins. This proportion strongly varies according to regions, because it can reach $64 \%$ in certain regions. Another study in 1980 [14] listed 35 different species of caterpillars in the south of the country. Knowing the ecological needs of certain species, the inhabitants search for young caterpillars to install them on particular trees near their residence, where they feed and grow on these trees. In the Yansi community, the consumption of caterpillars is regarded as a law and that of meat like an exception [24].

In Republic of Congo, the consumption of caterpillars around Brazzaville was estimated [25] to 30 grams per day per person. In the markets, Othoptera and the larvae of Rhynchophorus phoenicis are found particularly common and sold at very high prices.

In Zambia, the consumption of caterpillars is done during the rainy season (from November to February) and constitutes one of the princi- pal sources of proteins (more than $30 \%$ of the dry weights of the caterpillars). Mbunda distinguished 31 species of caterpillars, of which 7 are highly commercialised. Mbunda, Nkangala, Lucazi, Luvale, Cokwe and Yauma estimated that termites (adults of Macrotermes sp.) constituted the best foods, were more delicious than meat or fish and only some species of caterpillars could be compared to them [26]. In Madagascar, certain ethnic groups (18 ethnic groups) consume larvae of several insects. The most appreciated larva is that of Polists hebraeus, one local wasp. These larvae are collected in group together with the nest. Some larvae of Coleoptera (longicornes), an indigenous species Megopis mutica, an acclimatized species Batocera rufomaculata and possibly a species of charançon Aphiocephalus limbatus [27] which consume wood in decomposition are collected one by one in their natural habitats, and are consumed fried with butter alone or together with garlic and parsley.

In Cameroon, There are at least nine species of edible caterpillars in the south of Cameroon, and perhaps two species of larvae. In contrast to caterpillars, the larvae are consumed by all the populations in the south of Cameroon. There are two types of insect larvae on raphia trees, that is; the big type with dark caramel colour coming from the rotted trunks of raphia, and the small type with clearly brown colour coming from raphia trees growing in marshy areas. These larvae are usually called "phos" in Ewondo language. The caterpillars are fried and added to a sauce (tomato, cassava leaves, etc.), which is accompanied by cassava bread, boiled cassava, or "macabo". Otherwise, the larvae can also be eaten without accompaniment. There exists little specific literature to this subject, apart from the work of Dunias [28] on "white worms of palm tree", which underlines the fact that, although this resource is known (particularly in the Basin of Congo and in Cameroon), its exploitation is not sufficiently considered [11].

Malaisse [29] gives a good outline of the nutritional values of the caterpillars and confirms empirical knowledge of the local populations in a scientific way. To give an idea on their nutritional value, the average proportion of proteins, fats and average energy value of 24 species of fresh caterpillars were analyzed (table 1). The proximate composition of 14 species of edible insects collected in south western Nigeria [22], show that twelve species have protein contents of $20.0 \%$ and above. $R$. phoenicis has the highest value of ether extract (31.40\%) and the least value is found in $\mathrm{O}$ boas (table 2).

Compared with beef or fish, the insects have a high protein and fat proportion, and are thus extremely energetic (table 3). The proteins of the insects tend to be relatively low in particular 
Table 1. Average nutritional values of 24 edible caterpillars [29].

\begin{tabular}{|ll|}
\hline & Value (of Dry matter) \\
\hline Proteins & $63.5 \%$ \\
Fats & $15.7 \%$ \\
Energy value & $457 \mathrm{kcal} / 100 \mathrm{~g}$ \\
\hline
\end{tabular}

amino acids like methionine and cysteine, and contain many of other types, particularly lysine and threonine [30]. Moreover, chitin not being digestible makes the insects a source of bad quality proteins compared to food coming from vertebrate animals [31].

According to species, the caterpillars are rich in various minerals ( $\mathrm{K}, \mathrm{Ca}, \mathrm{Mg}, \mathrm{Zn}, \mathrm{P}, \mathrm{Fe}$ ) and/or vitamins (thiamine/B1, riboflavine/B2, pyridoxine/B6, pantothenic acid, niacin) (table 4). Studies show that $100 \mathrm{~g}$ of cooked insects provide more than 100 percent of the body needs in vitamins and minerals [30]. Malaisse [29] revealed that the daily consumption of $50 \mathrm{~g}$ of dried caterpillars satisfies the human requirements for riboflavin and pantothenic acid, as well as $30 \%$ of niacin requirement.

Because of their strong nutritional values in certain areas, the caterpillars are mixed with flour in order to prepare a pap to fight against the malnutrition of children. The species which are particularly rich in proteins (Imbrasia epimethea, Imbrasia dione, Antheua insignata), calcium (Tagoropsis flavinata) or iron (Cinabra hyperbius) are given to feeble people and to pregnant women with their breakfast. Several other species play a significant role in traditional medicines, as in the Chinese culture [32]. However, certain insects can secrete toxic substances coming from plants on which they feed or which they produce themsel-

Table 2. Chemical composition of some commonly eaten insects in south western Nigeria [22].

\begin{tabular}{|c|c|c|c|}
\hline Insects & $\begin{array}{l}\% \\
\text { Proteins }\end{array}$ & $\begin{array}{l}\% \\
\text { Fats }\end{array}$ & $\begin{array}{l}\% \\
\text { Ash }\end{array}$ \\
\hline $\begin{array}{l}\text { Macrotermes } \\
\text { bellicosus }\end{array}$ & 20.40 & 28.20 & 2.90 \\
\hline Brachytrypes spp. & 6.25 & 2.34 & 1.82 \\
\hline $\begin{array}{l}\text { Cytacanthacris } \\
\text { aeruginosus }\end{array}$ & 12.10 & 3.50 & 2.10 \\
\hline Zonocerus variegatus & 26.8 & 3.80 & 0.20 \\
\hline Analeptes trifasciata & 29.62 & 18.39 & 4.21 \\
\hline Anaphe recticulata & 23.00 & 10.20 & 2.50 \\
\hline Anaphe spp. & 18.90 & 18.60 & 4.10 \\
\hline $\begin{array}{l}\text { Rhynchophorus } \\
\text { phoenicis }\end{array}$ & 28.42 & 31.40 & 2.70 \\
\hline Cirina forda & 20.20 & 14.20 & 1.50 \\
\hline Oryctes boas & 26.00 & 1.50 & 1.50 \\
\hline Apis mellifera & 21.00 & 12.30 & 1.20 \\
\hline Anaphe venata & 25.70 & 23.21 & 3.20 \\
\hline
\end{tabular}

Table 3. Comparison of the nutritional values for $100 \mathrm{~g}$ of food [29].

\begin{tabular}{|lclccc|}
\hline Food & $\begin{array}{c}\text { Water } \\
{[\%]}\end{array}$ & $\begin{array}{l}\text { Proteins } \\
\text { [g] }\end{array}$ & $\begin{array}{l}\text { Fats } \\
\text { [g] }\end{array}$ & $\begin{array}{l}\text { Carbohydrates } \\
\text { [g] }\end{array}$ & $\begin{array}{l}\text { Energy value } \\
\text { [kcal] }\end{array}$ \\
\hline Fresh caterpillars & 81.1 & 10.6 & 2.7 & 4.2 & 86 \\
Dried caterpillars & 9.1 & 52,9 & 15.4 & 16.9 & 430 \\
Fried caterpillars & 20.4 & 62.3 & 4.6 & 6.5 & 333 \\
Fresh beef semi-fat & 63.1 & 18.2 & 17.7 & 0 & 273 \\
Dried beef, salted & 29.4 & 55.4 & 1.5 & 0 & 250 \\
Cooked beef & 68.5 & 22.6 & 8.0 & 0 & 172 \\
Fresh fish & 73.7 & 18.8 & 2.5 & 0 & 103 \\
Dried fish, salted & 13.8 & 47.3 & 7.4 & 0 & 269 \\
Cooked fish & 82.1 & 16.6 & 0.3 & 0 & 74 \\
\hline
\end{tabular}

ves [33]. Often, these species have colours which indicate or draw attention in another manner and hence are not collected. Generally, because of the high protein content of insects, they can replace meat and fish in the majority of the usual recipes. They are eaten rather salted than sweetened. There are multiple manners of preparing and of cooking the insects. Its recipes are inspired from the majority of methods of preparation used in African and Eastern traditional societies' haven consumed or which still consume these insects. The protein value varies according to insects between $10 \%$ and $86 \%$, and is $99 \%$ assimilable by the human organism.

\section{Insects consumed in Cameroon as potential sources of lipids and essential fatty acids}

\section{Material and methods}

The composition of oils extracted from the following six insects consumed in Cameroon was investigated: Raphia weevil (Rhynchophorus phoennicis); Crickets (Homorocoryphus nitidulus); Grasshopper (Zonocerus variegates); Termites (Macrotermes sp.); a variety of caterpillars
Imbrasia and an unidentified caterpillar from the forest (UI carterpillar).

Larvae of raphia tree weevil and Grasshopper were purchased from Mvog-mbi market of Yaounde (Center Cameroon). Crickets and termites were collected in Dschang (West Cameroon). Carterpillars (Imbrasia and an unidentified one), were purchased from a market in Sangmelima town (South Cameroon). The life samples were transported to the laboratory for confirmation of identity at the Department of Biology, University of Dschang, Menoua, Cameroon.

The insect larvae were killed by freezing [34, 35]. The frozen samples were then allowed to thaw at room temperature and dried in an oven at $50{ }^{\circ} \mathrm{C}$ for $72 \mathrm{hrs}$. The dried samples were ground into powder using a pestle and mortar and kept or stored in air-tight containers until required for subsequent analysis. The oil in the sample was extracted in Soxhlet using hexane as solvent and the lipid value (crude fat) was evaluated. The oil extracted after drying was put in a bottle and kept in the refrigerator until required for analysis.

The extracted fat was hydrolysed and the fatty acids converted to their methyl ester derivatives (FAME) using the method of test tubes [36]; while the GLC used was equipped with one

Table 4. Vitamin and mineral contents of some commonly eaten insects in south western Nigeria [22].

\begin{tabular}{|lccccccc|}
\hline Insects & $\begin{array}{l}\text { Vit. A } \\
(\boldsymbol{\mu g})\end{array}$ & $\begin{array}{l}\text { Vit. B } \\
(\mathbf{m g})\end{array}$ & $\begin{array}{l}\text { Vit. C } \\
(\mathbf{m g})\end{array}$ & $\begin{array}{l}\text { Ca } \\
(\mathbf{m g})\end{array}$ & $\begin{array}{l}\mathbf{P} \\
(\mathbf{m g})\end{array}$ & $\begin{array}{l}\text { Fe } \\
(\mathbf{m g})\end{array}$ & $\begin{array}{l}\text { Mg } \\
(\mathbf{m g})\end{array}$ \\
\hline Macrotermes bellicosus & 2.56 & 1.54 & 3.01 & 18.00 & 11.40 & 29.00 & 0.20 \\
Brachytrypes spp. & 0.00 & 0.03 & 0.00 & 9.21 & 126.9 & 0.68 & 0.13 \\
Cytacanthacris aeruginosus & 1.00 & 0.08 & 1.00 & 4.40 & 100.2 & 0.35 & 0.09 \\
Zonocerus variegatus & 6.82 & 0.07 & 8.64 & 42.16 & 131.2 & 1.96 & 8.21 \\
Analeptes trifasciata & 12.54 & 2.62 & 5.41 & 61.28 & 136.4 & 18.2 & 6.14 \\
Anaphe spp. & 2.78 & 0.09 & 3.20 & 7.58 & 122.2 & 1.56 & 0.96 \\
Anaphe venata & 3.12 & 1.25 & 2.22 & 8.57 & 100.5 & 2.01 & 1.56 \\
Cirina forda & 2.99 & 2.21 & 1.95 & 8.24 & 111.0 & 1.79 & 1.87 \\
Apis mellifera & 12.44 & 3.24 & 10.25 & 15.4 & 125.5 & 25.2 & 5.23 \\
Rhynchophorus phoenicis & 11.25 & 2.21 & 4.25 & 39.58 & 126.4 & 12.24 & 7.54 \\
Oryctes boas & 8.58 & 0.08 & 7.59 & 45.68 & 130.2 & 2.31 & 6.62 \\
\hline
\end{tabular}


FAME ionization detector (FID $260{ }^{\circ} \mathrm{C}$ ) and connected to a Hewlett Packard, model 5890A Hitachi Ltd, Tokyo, Japan, used to determine fatty acid constituents and their concentrations. The stationary phase comprised of 10\% SP 2300 silanized chromosorb (Supelco inc Belle fonte, pa/USA) packed in an omega Wax 320, 30 mm ID, 0,25 $\mu$ m film glass column of length $5 \mathrm{ft}$. The carrier gas (Helium) flowed at $2,5 \mathrm{~cm} / \mathrm{sec}$ set at $200{ }^{\circ} \mathrm{C}$ while injection, oven and column temperature was $250{ }^{\circ} \mathrm{C} 1 \mathrm{~mL}$ automatically in Split mode. The fatty acid peaks were identified with respect to reference co-chromatographed authentic fame standards.

\section{Results and discussion}

Table 5 shows the lipid value of the six insects and larva. The result shows that three of those insects and the larva are good sources of fat because; these values are equal or higher than 50\% (Raphia weevil, Crickets and Termites). These crude fat contents are more than $50 \%$ greater than the lipid range of 1.5 to $31.40 \%$, previously reported for various forms of lepidopterous coleopterous and Orthopterous edible insects from south western Nigeria [22] and are similar or fall within the lipid range of 4.2-77.2\% previously reported for seventy eight forms of edible insects from the State of Oaxaca, Mexico [37, 38] The caterpillars (Imbrasia or unidentified one) have lipid contents of about $20 \%$, which is similar to the range mentioned by literature. Grasshopper has the smallest quantity of lipids. Some insects or their larvae are potential sources of lipids.

The difference in lipid values between these insects or larvae and those cited in literature could be attributed to their differences in com-

Table 5. Fat content of some insects consumed in Cameroon.

\begin{tabular}{|ll|}
\hline Insects & Content (\% of dry matter) \\
\hline Raphia weevil (Rhynchophorus phoenicis) & 53.75 \\
Crickets (Homorocoryphus nitidulus) & 67.25 \\
Grasshopper (Zonocerus variegates) & 9.12 \\
Termites (Macrotermes sp.) & 49.35 \\
A variety of caterpillars Imbrasia & 24.44 \\
An unidentified caterpillar from the forest (UI carterpillar) & 20.17 \\
\hline
\end{tabular}

position, especially the fat contents and other calorigenic components of the larvae. These lipid contents are higher than the amount found in most conventional foods like beef, chicken, egg, Herring, Mackerel and milk [39], and are seen to contribute to its highly acceptable flavour when roasted or fried. Malnutrition in developing countries is as much or more, a problem of caloric deficiency [30]. The fat level implies that a $100 \mathrm{~g}$ sample of the larva will meet the caloric needs in most developing countries [40].

Table 6 shows the fatty acid composition of oils. The oil from raphia weevil mainly contains $37.60 \%$ of palmitoleic acid and $45.46 \%$ of linoleic acid and the ratio of PUFA/SFA is 16.70 (Polyunsaturated fatty acids/saturated fatty acids). The oil from crickets is made up principally of palmitoleic acid (27.59\%), linoleic acid (45.63\%) and $\alpha$-linolenic acid (16.19\%), the ratio of PUFA/SFA is 105.75 . The oil from grasshoppers is composed of palmitoleic acid (23.83\%), oleic acid (10.71\%), linoleic acid (21.07\%), $\alpha$-linolenic acid (14.76\%) and $\gamma$-linolenic acid (22.54\%) in the ratio 24.94 PUFA/SFA. The main components of termite oil are: palmitic acid $(30.47 \%)$, oleic acid (47.52\%) and linoleic acid (8.79\%) with a ratio of PUFA/SFA 0.23. Palmitic acid (36.08\%) and linolenic acid (38.01\%) are the two dominant fatty acids of Imbrasia oil. The ratio of PUFA/SFA is 1.01 . With a ratio of PUFA/SFA 1.25 and as Imbrasia oil, UI caterpillar oil is compose of palmitic acid (30.80) and linolenic acid $(41.79 \%)$ in presence of stearic acid (7.04\%), oleic acid (8.56\%) and linoleic acid (6.59\%). Apart from oil from termites, these oils are rich in polyunsaturated fatty acids. This value when compared to oils from most conventional sources is quite high. These oil contents were more than $35.5 \%$ and $29.6 \%$ reported for poultry and fish respectively, near or more greater than $52.0 \%$ and $44.1 \%$ reported for beef and pork respectively [41].

Saturated fatty acids found in the larva included lauric acid, myristic acid, palmitic acid; palmitoleic acid and stearic acid. They contain a high amount of polyunsaturated fatty acids, linolenic acid and linoleic acid. Palmitic acid as well as myristic acid have been demonstrated to raise low density lipoprotein (LDL) cholesterol and are therefore considered atherogenic [42].

However, stearic acid which constitutes nearly $2.35 \%$ of the saturated fatty acid in the larva has been shown not to raise plasma LDL cholesterol [43]. Oleic acid, a monounsaturated fatty acid, has been shown to be hypocholesterole-

Table 6. Fatty acid composition of raphia weevil, cricket, grasshopper, termites, Imbrasia and UI carterpillar.

\begin{tabular}{|c|c|c|c|c|c|c|}
\hline & Raphia weevil & Cricket & Grasshopper & Termites & Imbrasia & UI carterpillar \\
\hline Lauric acid (C12:0) & 0.12 & & & & & \\
\hline Myristic acid (C14:0) & 2.50 & 0.59 & & 0.81 & & 0.98 \\
\hline Palmitic acid (C16:0) & 0.20 & & & 30.47 & 8.42 & 30.80 \\
\hline Palmitoleic acid (C16:1) & 37.60 & 27.59 & 23.83 & 2.21 & & 0.73 \\
\hline Stearic acid (C18:0) & 0.23 & & & 9.03 & & 7.04 \\
\hline Oleic acid (C18:1n-9) & 5.24 & 6.89 & 10.71 & 47.52 & 9.06 & 8.56 \\
\hline Linoleic acid (C18:2n-6) & 45.46 & 45.63 & 21.07 & 8.79 & 6.88 & 6.59 \\
\hline$\alpha$-linolenic acid (C18:3n-3) & 4.19 & 16.19 & 14.76 & 0.63 & 38.01 & 41.79 \\
\hline$\gamma$-linolenic acid (C18:3n-6) & 1.215 & 0.58 & 22.54 & & & \\
\hline Gondoic acid (C20:1) & 0.79 & 0.28 & & & & \\
\hline Erucic acid (C22:1) & & & & & 0.94 & \\
\hline SFA & 3.05 & 0.59 & 2.34 & 40.31 & 44.50 & 38.82 \\
\hline UFA & 94.49 & 97.14 & 93.32 & 59.14 & 54.89 & 57.67 \\
\hline MUFA & 43.63 & 34.75 & 34.96 & 49.73 & 10.00 & 9.29 \\
\hline PUFA & 50.86 & 62.39 & 58.36 & 9.41 & 44.89 & 48.38 \\
\hline $\mathrm{P} / \mathrm{S}$ & 16.70 & 105.75 & 24.94 & 0.23 & 1.01 & 1.25 \\
\hline
\end{tabular}




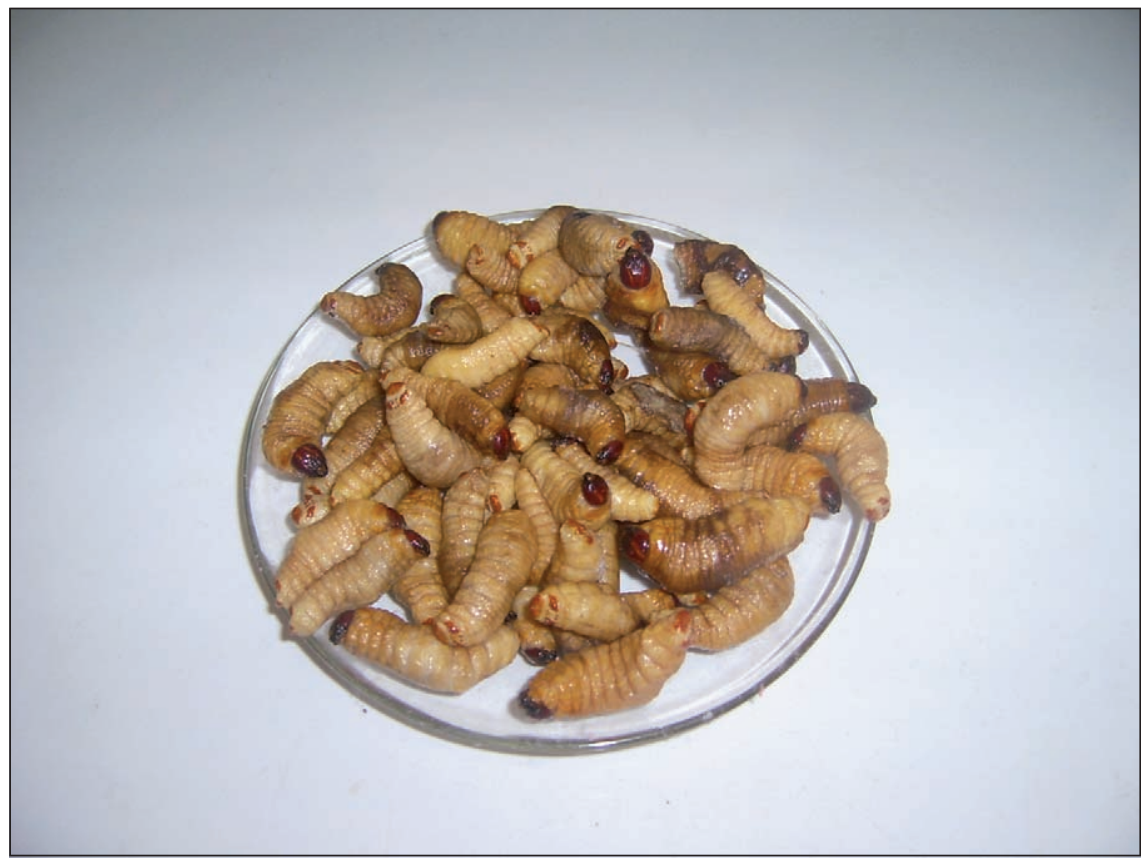

Figure 1. Raphia Weevil (Rhynohophorous Phoenicis).

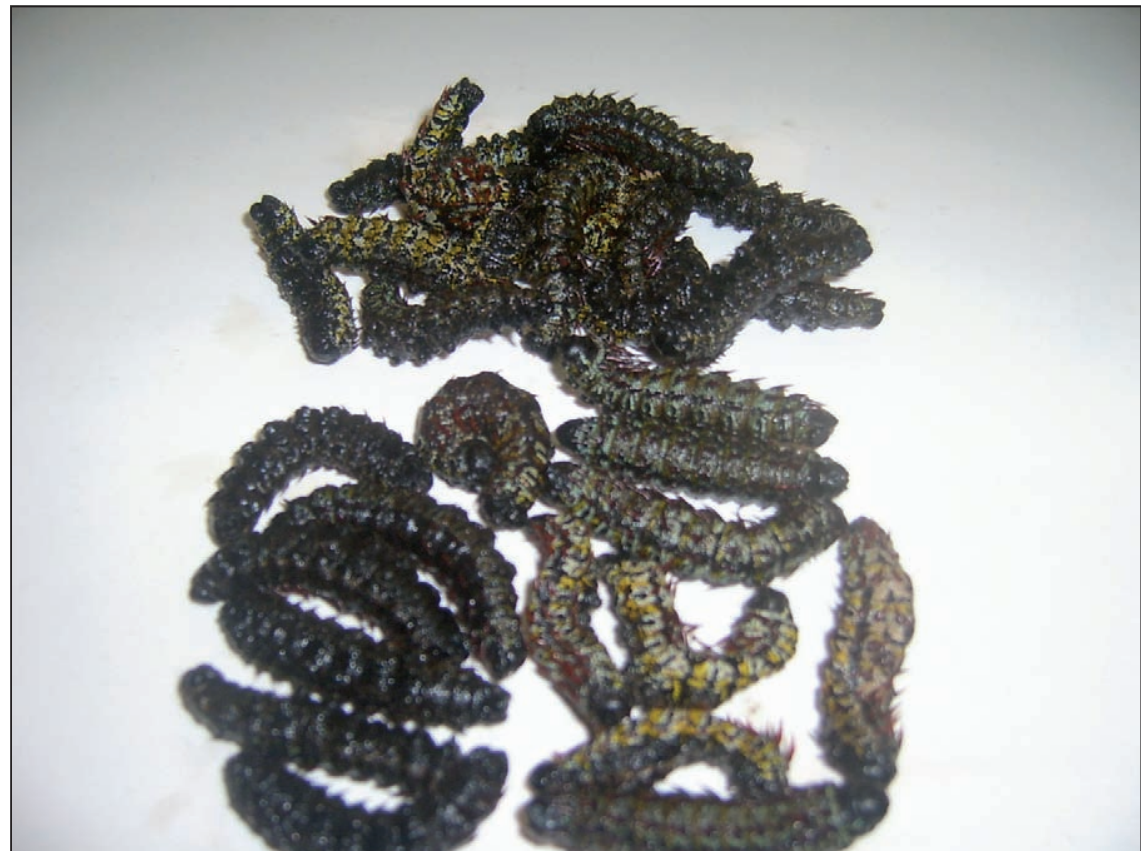

Figure 2. A variety of caterpillars Imbrasia

mic [10]. Ratio of polyunsaturated to saturated fatty acids $(P / S)$ has been used widely to indicate the cholesterol lowering potential of a food. A P/S ratio of 0.2 has been associated with high cholesterol level and high risk of coronary heart disorders while a ratio as high as 0.8 is associated with desirable levels of cholesterol and reduced coronary heart diseases [44]. The $\mathrm{P} / \mathrm{S}$ ratios of $16.70,105.75$ and 24.94 for raphia

\section{Conclusion}

Edible insects contribute to the diet of various populations of the world. In Africa more than
500 species of insects are used as food and some do have a significantly high food value. Some contain proteins as meat and fish while others are rich in fat and contain significant minerals and vitamins. Animal proteins being expensive for the underprivileged class, the hypercholesterolemic effects of certain foods and the scarcity of savage animals have significantly encouraged entomophagy. The fatty substances of insects had an effect on the reduction of cardiovascular and digestive diseases. Edible insects must be regarded as a potential alternative to improve food security. These results show that these insects are considerable sources of fat. Their oils are rich in polyunsaturated fatty acids, of which essential fatty acids are linoleic and linolenic acids. The ratio PUFA/SFA, in the majority of cases are higher than 0.8, associated with desirable levels of cholesterol, suggest that the insects have the potential of being used in the dietary management of certain coronary heart diseases. The consumption of these insects would compensate the insufficiency of essential fatty acids brought mainly by tropical vegetable oils. Due to the fact that: oils from insects are rich in polyunsaturated fatty acids, they are more likely to undergo oxidation and since these insects are not consumed fresh, heat treatments during cooking of the insects must be accorded a lot of attention. Also, particular attention must be given to the effect of culinary treatments and conservation on the lipid profiles and the quality of proteins of the insects (figure 1 et 2).

\section{REFERENCES}

1. Yoloye VL. Basic Invertebrate Zoology, $1^{\text {st }} E D$. University of Ilorin Press. Ilorin, 1988.

2. Ene JC. Insects and man in West Africa. Ibadan University Press. Ibadan, 1963.

3. Goodman WG. Chitin: a magic bullet? The Food Insect Newsletter $1989 ; 3$ : 6-9.

4. Sutton MQ. Insects as food: aboriginal entomophagy in the Great Basin. Ballena Press Anthropological Papers No. 33. Ballena Press. Menlo Park: Californie, 1988.

5. Mwizenge ST. Delicious insects: seasonal delicacies in the diet of rural Zambians. World and $11993 ; 8: 234$.

6. Robert K. The aapplication of industrial technology for production of insects as food. The Food Insect Newsletter $1989 ; 3: 3$.

7. Anthonio HO, Isoum M. Nigerian Cookbook. London : Macmillan Press, 1982.

8. Ashiru MO. The food value of the larva of Anaphe venata Butler (Lepidoptera: Notodoutidae). Ecol Food Nutr 1988 ; 22 : 313-20.
9. Fasoranti JO, Ajiboye DO. Some Edible Insects of Kwara State Nigeria. American Entomologist $1993 ; 9: 113-6$. 
10. Mensink RP, Katan MB. Effect of a diet enriched with monounsaturated or polyunsaturated fatty acids on the levels of low-density and high density lipoprotein cholesterol in healthy women and men. N Engl J Med 1989; 321 : 436-41.

11. Balinga MP. Les chenilles et larves comestibles dans la zone forestière du Cameroun. Rapport de Consultation. Rome : FAO, 2003.

12. Ramos-Elorduy J. Creepy crawly cuisine. The gourmet guide to edible insects. Part Street Press (Rochester, Vermont): xi + 150 p. 1998

13. Kondondi KK, Leclercq M, Gaudin-Harding F. Vitanmin estimations of three edible species of Attacidae caterpillars from Zaine. Int / Vitam Nutr Res 1987 ; 57 : 333-4.

14. Nkouka O. Les insectes comestibles dans les sociétés d'Afrique centrale. Muntu 1987; 6 : 171-8.

15. Letters BG. Food Insects Newsletter $1993 ; 6: 7$.

16. Bani $\mathrm{G}$. Some aspects of entomophagy in the Congo. Food Insects Newsletter $1995 ; 8$ : 4-5.

17. De Foliart GR. Insects as food: why the western attitude is important. Ann Rev Entomol 1999; $44: 21-50$.

18. Gomez PA, Halut R, Collin A. Production de protéines animales au Congo. Bull Agric Congo $1961 ; 52: 689-815$.

19. Oliveira JFS, Passos de Carvalho SJ, Bruno de Sousa RFX. Magdalena Sinao. The nutritional value of four species of insects consumed in Angola. Ecol Food Nutr $1976 ; 5$ : $91-7$.

20. Banjol AD, Laval OA, Songonuga EA. The nutritional value of fourteen species of edible insects in southwestern Nigeria. African Journal of Biotechnology $2005 ; 5$ : 298-301.

21. Malaisse F, Parent $G$. Les chenilles comestibles du shaba meridional (Zaire). Nat Belge 1980; $63: 2-24$.

22. Banjo $A D$, Laval $O A$, Songonuga EA. The nutritional value of fourteen species of edible insects in southwestern Nigeria. African Journal of Biotechnology $2005 ; 5$ : 298-301.
23. Muaya T. Les Insectes comme Aliments de I'Homme. Pubn. Sér. II, vol. 69, CEEBA (Bandundu, Zaïre), 1981 : 177 p.

24. Silow CA. Edible and others insects of midwestern Zambia. Studies in ethnoentomologie II. In: Occas. Pap V Allm Jamforand Etnogr (Uppsala), Almqvist \& Wikseel: 233, p. 1976.

25. Silow $C$. Notes on Ngangala and Nkoya ethnozoology, ants and termites. Philos Trans $R$ Soc London $1983 ; 71: 139-92$

26. Ruddle K. The human use of insects: examples from the Yukpa. Biotropica 1973 ; 5 : 94-101.

27. Dufour DL. Insects as Food: A Case Study from the Northwest Amazon. American Anthropologist $1987 ; 89$ : 383-97.

28. Dunias E. L'exploitation d'une ressource bien connue: la récolte des larves comestibles de charançons dans les palmiers raphia au Cameroun, 1999.

29. Malaisse F. Se nourrir en forêt claire africaine. Approche écologique et nutritionnelle. Les Presses agronomiques de Gembloux. Centre technique de coopération agricole et rural. Wageningen: Gembloux, 1997.

30. De Foliart GR. Insects as Human Food. Elsevier Science (publishers), 1992: 295-399.

31. Dreyer IJ, Wehmeyer AS. On the nutritive value of mopanie worms. South African Journal of Science $1982 ; 78: 33-5$.

32. Chen $X$, Feng Y. Review on nutritive value of edible insects. Chinese Forestry Science and Technology $2002 ; 1: 54-9$.

33. Duffey SS. Sequestration of plant natural products by insects. Ann Rev Entomol 1980 ; 25 : 447-77.

34. Finke MD, De Foliart GR, Benevenga NJ. Use of a Four-Parameter logistic model to evaluate the quality of proteins from three insect species when fed to rats. / Nutr $1989 ; 119: 864-71$.
35. Adedire CO, Aiyesanmi AF. Proximate and mineral composition of the adult and immature forms of variegated Grasshopper, Zonocerus (L). Bioscience research communications 1999; 11: 121-6.

36. Gunstone FD. An introduction to the chemistry and Biochemistry of fatty acids and their glycerides. UK : Chapman and Hall Ltd, 1969.

37. Ramos-Elorduy J, Moreno JMP, Prado EE, Perez MA, Otero JL, de Guevara OL. Nutritional value of edible insects from the State of Oaxaca, Mexico. Journal of Food Composition and Analysis $1997 ; 10: 142-57$.

38. Ekpo KE, Onigbinde AO. Nutritional potentials of rhynchophorus phoenicis. Pakistan Journal of Nutrition $2005 ; 4$ : 287-90.

39. Pyke M. The Science of Nutrition. In: Science in Nutrition. John Murray (publishers) Ltd., London, 1979: 251-8

40. Davidson S, Pasmore R, Brock JF. Human nutrition and Dietetics (5th edition). The English language Book Society. London: Churchill Livingstone, 1973: 77

41. De Foliart RG. Insects Fatty acids: Similar to those of Poultry and Fish in their degree of unsaturation but higher in the Polyunsaturates. The Food Insects Newsletter 1991 ; IV : 1-4.

42. Willett WC, Sacks FM. Sterol Content of Foods of Plant Origin. In: Akinnawo O, Ketiku AO (Eds). Chemical Composition and Fatty Acid Profile of Edible Larva of Carina forda (westwood). Afr J Biomed Res 1991; 3: 93-6.

43. Bonamone A, Grundy SM. Stearic acid does not raise serum cholesterol. Clin Res 1987; 35 : 365-9.

44. Mann J. Diseases of the heart and circulation: the role of dietary factors in aetiology and management. In: Garrow JW, James, eds. Human Nutrition and Dietetics. London: Churchill, Livingstone, 1993 : 619-50. 